\title{
THE THEOLOGY OF TOLERANCE IN HINDU AND ISLAM: MAINTAINING SOCIAL INTEGRATION IN LOMBOK - INDONESIA
}

\author{
Suprapto \\ State Islamic Institute (IAIN) Mataram \\ Email: praptontb@yahoo.com
}

\begin{abstract}
This article seeks to examine the theology of tolerance as the basis for interreligious and harmonious co-existence between Muslims and Hindus in Lombok. Lombok is known as the island of thousand mosques where majestic mosques scatter throughout the island. But Lombok is also a home for Hindus. The interactions between them have been very dynamics, creating integration, acculturation, adaptation, accommodation while sometimes also triggering tension. This article argues that theology occupies important aspects in both Hindu and Muslim daily live and thus can be employed as the solid basis of interreligious relations between them. From the Islamic perspective, there are a number of Qur'anic verse injuctions for tolerance. Hindus are also required to maintain tolerant attitude towards other religions as this is commanded in the Veda. These theological grounds will strengthen from the faith point of view Hindu-Muslim social cohesion, which has so far been realized though various means, such as music, arts and religious festivals.
\end{abstract}

Keywords: theology of tolerance, Hindu, Islam, social integration, Lombok

DOI:http://dx.doi.org/10.20414/ujis.v19i2.358 


\section{Introduction}

IN LOMBOK Indonesia, the relation between the Hindu and Muslim communities tends to lead to integration and harmony rather than conflicts and tensions. Their social integration constitutes acculturation, adaptation, accommodation, assimilation and cooperation. It is interesting to $\mathrm{c}$ note that the integration between the Hindus and Muslims appear in several domains. ${ }^{1}$

Acculturation process can be observed in the activities of those communities in which they adopt several cultural elements from each other. Hindu-Balinese has influenced Islam-Sasak. Similarly, Hindu-Balinese adopts some of the cultural aspects of Islam-Sasak. In addition, the assimilation through inter-ethnic marriage is one of the social integration processes.

Social integration in Mataram is preserved by quotidian social bonding, not formal associations. Several formal associations, which are established forcefully and not based on people's initiatives, do not contribute significantly to healthy social integration. Instead of bridging communities, such organizations sometimes fail to build intra-communal bonding. As a result, the organizations expected to contribute to social cohesion create conflicts of interests. The following description elaborates deeply integration patterns and its contributing factors. One of the most fundamental factors is theology of harmony in both religions: Islamic teaching and Hinduism.

\section{Domain of Social Integration}

Integration in the Socio-Cultural Domain: Arts and Traditional Costumes

The results of acculturation between Hindu-Balinese and Islam-Sasak cultures can be seen in their traditional art performance, costumes, languages and traditions prevailing in Lombok society at this time. It can be observed that existing Lombok, especially in Mataram and West Lombok, traditional

'Based on Karin Peters' perspective, social integration takes place in three great domains: (1) political, (2) socio-economic and (3) socio-cultural domains. See Karin Peters, Living Together in Multi-Ethnic Neighborhoods: The Meaning of Public Spaces for Issues of Social Integration (Wageningen: Wageningen Academic Publisher, 2011), 73. 
arts of Sasak are influenced by that of Hindu-Balinese. Correspondingly, several Islam-Sasak cultures can be obviously seen in traditional Hindu-Balinese arts in Lombok.

Such cultural exchange is a logical consequence of the interaction between two communities that have been established for hundreds of years. One example of acculturation can be viewed in traditional Lombok orchestra. The strains of note in traditional Lombok orchestra highly resemble that of Balinese. When we listen or watch gendang beleq (big drum) performance, for example, we feel as if we listened to the dynamic Balinese rhythm. ${ }^{2}$

Traditional Lombok art performance, besides the fact that they are a result of acculturation, is an effective means of social integration. This can be noticed in a great number of traditional music groups in Lombok whose members come from both communities. One of those is Pegongan Samsan Gadang, a traditional music group led by Made Bambang, a Hindu. The group involves sekehe (gamelan players) from Balinese and Sasak ethnic groups. ${ }^{3}$

The following description shows how the integration happens:

"Our traditional music group, as I am developing now, is often invited to play in the Sasak feasts. Similarly, when the Balinese need gamelan instruments, either for feast or religious prayers, they borrow it from the Sasaks. I also often ask my Sasak friends from Sembung to be gamelan players. Papuk Darum, an angklung player, is a Sasak. He is often requested to play in some Balinese ceremonies such as wedding or ngaben (cremation)." 4

2It is called gendang beleq because one of the instruments used is a huge traditional drum; beleq is a Sasak word for huge. The main instruments in gendang beleq are two huge traditional drums; gendang mama (male drum) and gendang nina (female drum), which function to create dynamics. Other instruments are gendang kodeq (small drum), two cackles bringing melody consisting of reog mama (two tones) and reog nina, perembak beleq and eight perembak kode (or called copek). These Perembaks function as rhythm instruments.

${ }^{3}$ Sekehe (or Seke in Balinese) is a gamelan player.

4Interview with Made Bambang, on 18 July 2011. 
It is conceived that music and arts play a significant role in breaking primordial boundaries and enhancing social harmony. Through arts, the Hindu-Balinese and the Muslim-Sasak communities engage in an intensive interaction regardless of their diverse ethnicity and religious backgrounds. As it has been suggested by David Harnish, music is the vehicle of dialogues and the means of experience sharing among different ethnic groups. ${ }^{5}$

In regard to agriculture, when people greatly need sufficient water, some rituals and cultural attractions, such as a traditional game of gebug rotan or peresean, are performed. Peresean is a fight between pepadu-pepadu Sasak (masters of martial arts) who use rattan sticks and shields to attack and defend themselves. The fight takes place in a field and is watched by many people. Under a referee, both pepadus fight, hit, and beat against each other. Peresean has been practiced in some of Lombok areas until now. Recently, the local government has actively sponsored peresean and allowed it as a cultural performance that attracts tourists.

Another example of Balinese and Lombok acculturation can be noticed in Bali and Sasak scripts. ${ }^{6}$ Both Balinese and Sasaks have the same form of letters and closely resemble the Javanese script, which is called hanacaraka. Lombok people pronounce the letters anecarake and they denominate them as jejawen characters. The difference lies in the number of characters; the Javanese script has 20 characters whereas the Balinese and Lombok scripts have 18 characters. The jejawen script was found in several Lombok manuscripts written on palm leaves or daluwang papers. ${ }^{7}$

5David Harnish, "New Lines, Shifting Identities: Interpreting Change at the Lingsar Festival in Lombok, Indonesia," Ethnomusicology, Vol. 49, No. 1 (Winter, 2005): 1-24 http://www.jstor.org/stable/20174351. (Accessed on 12 February 2012).

6 See I Nengah Tinggen, Pedoman Perubahan Ejaan Bahasa Bali dengan Huruf Latin dan Huruf Bali (Singaraja: UD. Rikha, 1993).

${ }^{7}$ The use of jejawen script has decreased since Muslims used the Arabic characters both in Malay writings (known as the Jawi script) or in Arabic writings (known as (the Arab pegon script). A more detailed explanation about this topic can be seen in Poerbatjaraka, P. Voorhoeve, and C. Hooykaas, Indonesische Handschriften (Bandung: A.C.Nix\&Co,1950), 75; and 


\section{Integration in the Daily Life}

Interaction between Hindus and Muslims in their daily lives happens in peace. Both do their activities together, for example in markets and shopping centers, schools, farmlands and other public spaces. In various public spaces -in their tangible forms, people interact and communicate one another. In traditional markets, Hindu merchants sell their merchandise to Muslim buyers and vice versa. Such interaction can be observed in a number of traditional markets in Mataram such as Karang Lelede, Sindu, Cakranegara, Bertais, Muhajirin Dasan Agung, Cemara and others.

In Karang Lelede Market, for example, Muslims' groceries are sold side by side with Hindus' offerings and ritual goods such as flowers, incense, young coconut leaves, bamboo plaits and others. The Muslims from villages nearby Mataram such as Gunung Sari and Narmada supply those goods required for the Hindu's rituals. Similarly, the Muslims from Gunung Sari supply nira, the sap of palm tree used as raw materials for making tuak (alcoholic drink) sold in the Hindu community.

Two-wheeled buggy drivers and public transport motorcycle riders, who are Muslims, always provide their service for HinduBalinese passengers. Outside Karang Lelede Market, Ibu Nursiyah, a pelecing (a unique Lombok food made from water spinach) seller who based at the side of the Palapa Road also has customers from both Muslim and Hindu communities in the vicinity, such as Karang Tapen, Karang Lelede and the Karang Jasi. Similarly, Mak Wayan, a Hindu grocer whose employees are Sasak-Muslim girls, sells her agricultural goods to Muslim buyers in Dasan Agung Market.

The good interaction between Muslim and Hindu traders in traditional markets reduces various rumors and gossips spread in the society. For example, several years ago in Sindu Market Muslim chicken sellers from Karang Taliwang prevented the spread of rumor about the plan of the attack of Hindu community's in Sindu against the Muslim community in Karang Taliwang. This occurred in a couple of days after the tension

Th.G. Pigeaud, Literature of Java. Vol I. Synopsis of Javanese Literature 900-1900 $A D$ (The Hague: Martinus Nijhoff, 1967), 26. 
between the Karang Taliwang Muslim community and the Hindus in Tohpati and Sindu took place. Consequently, the Muslim community from kampongs nearby Sindu, who were ready to attack Hindu kampongs, canceled their plan.

Quotidian social bonding in Ashutosh Varshney's term has been proved to be effective in building and bridging different ethnicities and religions in Mataram. This fact differs from Varshney's finding in India in which quotidian social bonding in daily lives was less effective than the associational social bonding in peacekeeping. ${ }^{8}$

In addition, peaceful interaction between Hindus and Muslims can be observed in religious feast. As Ied-ul Fitr feast approaches, many Muslims visit sacred tombs near Hindu kampongs such as in Pemakaman Muslim Karang Bedil. The Hindus near the cemetery sell flowers to Muslim visitors.

\section{Participation in Religious Festivals and Rituals}

It is interesting to note that in the harmony between HinduBalinese and Muslim-Sasak communities both involve in some religious festivals and rituals. The Muslim community considers that such participation is more cultural rather than theological. Both communities participate in each other cultural events by attending festivals and providing assistances either physically and financially.

One religious festival involving both communities is perang topat (theatrical war of rice cake wrapped in coconut leaves). Perang topat has been an annual tradition conducted in Lingsar Temple or Lingsar Park, in Lingsar, West Lombok, since the one hundred year old temple was built. Both Hindu and Muslim communities have a sense of belonging to this temple.

Muslim-Sasak people denominate Hindu Lingsar Temple as kemalik Lingsar. Kemalik means a sacred place where Datu Sumilir, an Islamic missionary, spread the teaching of Islam. Not only the Hindus do prayers in this temple, but also MuslimSasak and Buddhist-Chinese people perform some rituals there. The government of West Nusa Tenggara province decided the temple as a cultural heritage.

${ }^{8}$ Ashutosh Varshney..., 12. 
Perang topat ritual is conducted in purnama saseh according to the Balinese calendar or in bulan pitu according to the Sasak calendar, i.e. from November to December every year. Thousands of Muslims and Hindus come to Lingsar Temple or Park and do a mimic warfare by throwing ketupat (rice cakes boiled in a rhombus-shaped packet of plaited young coconut leaves). They then pick the ketupat and bring them home. They believe that the ketupat can increase their harvest in farming or fishing. They spread the ketupat in their gardens, rice fields or fishponds.

There are several aims and intentions of annual perang topat. According to Harnish, there are at least four functions of perang topat. (1) as a means of communication to God, (2) a prayer for soil fertility, human, blessings, rain and recovery, (3) a forum in which both Hindus and Muslims raise a pride of their past histories and ancestors as well as build socio-religious identity, and (4) a connection between the past and the present and means of self-adjustment to the present and the future needs. ${ }^{9}$

Lingsar Temple is a vehicle for building mutual understanding between Hindu-Balinese and Muslim-Sasaks. This can be observed from displacement of worshipped animal statues in the temple areas during the perang topat festival. It also has been known that the slaughter of pigs and cows is prohibited. Pigs are forbidden for Muslims while cows are sacred to Hindus. Considering this, both Hindus and Muslims agree to slaughter a buffalo. This is seen as a win-win solution for both parties.

Muslims' participation in Hindu religious and cultural events also can be observed in ogoh-ogoh (statues built in the forms of mythological beings, mostly demons, representing evil spirits) parade. Some of Muslims watch the parade, act as the players of musical instruments and help the making of ogoh-ogoh which costs relatively a lot of money. In this annual festival, the ogoh-

${ }^{9}$ David Harnish, "New Lines, Shifting Identities: Interpreting Change at the Lingsar Festival in Lombok, Indonesia," Ethnomusicology, Vol. 49, No. 1 (Winter, 2005): 1-24, http://www.jstor.org/stable/20174351 (accessed on 12 February 2012). 
ogoh is paraded in the evening of Nyepi (silence) day. ${ }^{10}$ Almost all Balinese kampongs or banjar make different forms of ogoh-ogoh. ${ }^{11}$ In the Nyepi day in 2012, there were approximately 150 ogoh-ogoh parades.

\section{Contributing Factors of Social Integration}

\section{Theology of Tolerance}

Various social interactions described above develop due to diverse factors particularly theology. Theological foundation of interreligious relation can be traced to at least two things: Scripture and religious teaching understanding. There is a common belief that no religion teaches hatred, frictions, and blasphemies against other religions. All religions teach harmony and peace. Nonetheless, different backgrounds of religious adherents create diverse understandings about their religious teachings.

Educational background, psychological condition, the level of socialization, socio-political situation and history of religious adherents greatly influence their different understandings. Diverse psychological and socio-cultural backgrounds create various interpretations of religious values. It is common that adherents of the same religion understand and interpret the similar text of their Scripture differently.

Regarding the diversity of understanding, Khaled Abou elFadl stated: "The meaning of the text is often as moral as its

${ }^{10}$ Nyepi festival is performed in Tilem Kesanga (the ninth month) or the dead moon or approximately in March, which is I saka (I cakawarsa) Hindu New Year. One day before Nyepi, the ogoh-ogoh parade is performed. Then, all Hindus perform Nyepi for 24 hours. Nyepi is known as catur brata rituals consisting of amati geni (not using light), amati karya (not working), amati lelungan (not traveling) and amati lelangunan (not having any entertainment). Regarding Hindu festivals, see Tim Penyusun Parisada Hindhu Dharma, Upadesa tentang Adjaran-adjaran Agama Hindu, (Jakarta: Penerbit Sub Projek Bimbingan Penyuluhan dan Dakwah Direktorat Jendral Bimas Hindu dan Budha Depag RI, 1970).

${ }^{11}$ According to the festival chairman, in order to welcome Nyepi in Saka Year of 1932, there were 150 ogob-ogoh in the parade. http:/ / oase.kompas.com/read/2010/03/13/12272878/ (accessed on 9 May 2012). 
reader."12 In other words, people's religiosity influences their understanding about their religion. If they are exclusive, so are their understanding and interpretation. Conversely, if they have inclusive worldviews, they will understand their religion inclusively. This section does not elaborate the debate on elFadl's conviction. Which does influence more: a reader's morality or religious teachings? It is assumed that a reader's morality is constructed after he or she understands his or her religious teachings. Actually, every religion motivates its adherents to respect other religions. The teaching of religion influences the behaviors of its community. Inclusive religious teachings lead people to be inclusive to others.

Apart from that debate, it is interesting to note how Hindu and Muslim communities understand their religious teachings particularly related to the existence of others. ${ }^{13}$ It is also important to look at religious community's views against other religions because these reflect local people's worldviews. ${ }^{14}$

The following description summarizes various comments and views regarding diversities in religions and beliefs and their responses. Prior to that, several basic Islamic and Hindu teachings that promote interreligious peace and recognize religious freedom as one of human rights are explained.

${ }^{12} \mathrm{El}-\mathrm{Fadl}$, a Kuwait thinker, explained, "The meaning of the text is often as moral as its reader. If the reader is intolerant, hateful, or oppressive, so will be the interpretation of the text." See Khaled Abou el Fadl, The Place of Tolerance in Islam (Boston: Beacon Press, 2002), 23; see also Khaled Abou El Fadl, Speaking in God's Name: Islamic Law, Authority and Women (Oxford: One World Publication, 2001).

13 Understanding religious languages is essential to see the religious contribution to the development of social cohesion even in a secular society or state. Rhys H. Williams, "The Language of God in the City of Man: Religious Discourse and Public Politics in America" in Religion as Social Capital: Producing the common good, ed. Corwin Smidt (Waco, Texas: Baylor University Press, 2003): 171-190.

${ }^{14}$ Learning such understanding is valuable to look social integration process and explore possible conflicts detected through cultural articulation and contestation between different ethnicities and religions. See Marc Howard Ross, Cultural Contestation in Ethnic Conflict (New York: Cambridge University Press, 2007), 17. 
In Islam, the basic principle of interreligious tolerance and peace can be read in several Quranic verses and hadith. In the Qur'an, Chapter Yūnus (10): 99, Allah says:

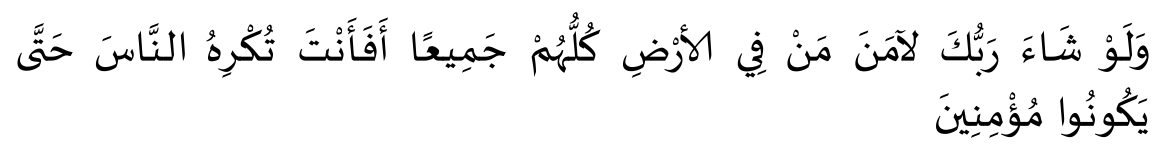

"And had your Lord willed, those on earth would have believed, all of them together. So, will you then compel mankind until they become believers."

In this verse, God obviously says that plurality is a certainty; it is given in nature. Therefore, a wish to make all humans adherent to the same religion is not only absurd, but also contradictory to God's decree. Allah further says explicitly about plurality in the Qur'an, Chapter al-Mà'idah (5): 48:

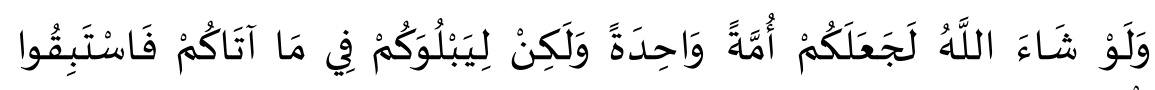
الْخَنْرَاتِ تُعِ

"If Allah willed, He would have made you one nation, but that He may test you in what He has given you; so strive as in a race in good deeds."

From that verse, it is evident that Allah has made human beings diverse although $\mathrm{He}$ has power and authority to make them into one nation. According to exegeses, the word 'لَو ("law") in this verse, in Arabic grammar, is used as "a parable that means improbability". ${ }^{15}$ Such 'لَ ' "law") is also employed in the Quran, Chapter Hūd (11): 118.

$$
\text { وَلَوْ شَاءَ رَبُّكَ لَجَعَلَ النَّاسَ أُمََّةً وَاحِدَةً }
$$

"And if your Lord had so willed, He could surely have made mankind one ummah (nation or community following one religion)".

This verse obviously states that diversity or plurality is Allah's will. ${ }^{16}$

15See al-Husain bin Muhammad al-Raghib al-Asfahani, Mujjam alMufradat li Alfäzdh al-Qur'ān (Beirut: Dār al-Kutub al-'Tlmiyya, 1997), 108.

${ }_{16} S e e$ 'Abd Allāh bin Muḥammad bin Aḥmad al-Anșāir al-Qurṭubi, AlJāmi’ li Ahkām al-Qur'ān (Egypt: Dār al-Kutub al-Miṣriyya, n.d), 114-115. 
Humans' inclination to a religion is a logical consequence of their reason bestowed by God. There is no coercion in religion as the Qur'an Chapter al-Baqarah (2): 256 says.

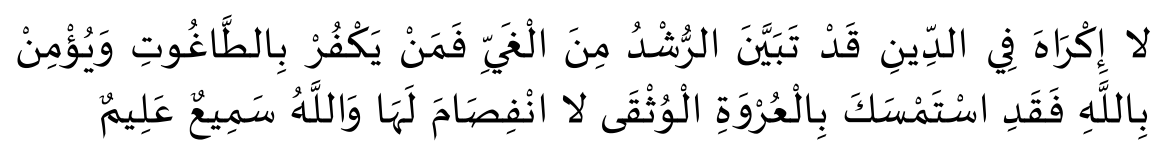

There is no compulsion in religion. Verily, the right path has become distinct from the wrong path. Whoever disbelieves in Taghut and believes in Allah, and then he has grasped the trust worthiest handhold that will never break. And Allah is AllHearer, All-Knower."

According to Ibn Jarïr's report from Saìd from Ibn Abbās, asbäb al-nuzūl (historical background) of that verse is an event relating to Husayn (a Muslim from Anșār group from Bani_Salīm tribe), who had two Christian children. He asked the Prophet Muhammad, "May I compel my children because they disobey me and insist on being Christians?" The verse was revealed regarding that issue. In the Qur'an, Chapter al-Hajj (22):17, Allah says:

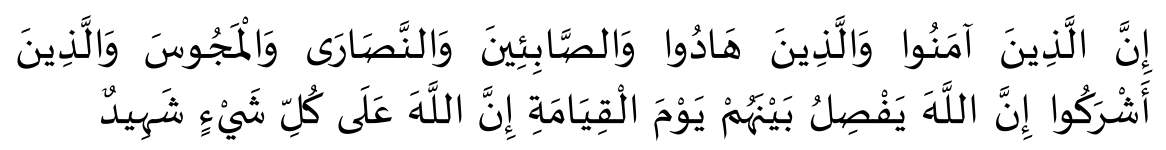

"Verily, those who believe in Allah and in His Messenger Mubammad, and those who are Jews and the Sabians and the Christians, and the Magians, and those who worship others beside Allah, truly, Allah will judge between them on the day of Resurrection. Verily! Allah is Witness over all things."

Muslims are also forbidden from blaspheming and reviling other religious communities. The Qur'an Chapter al-Hujurāt (49):12 explicitly says:

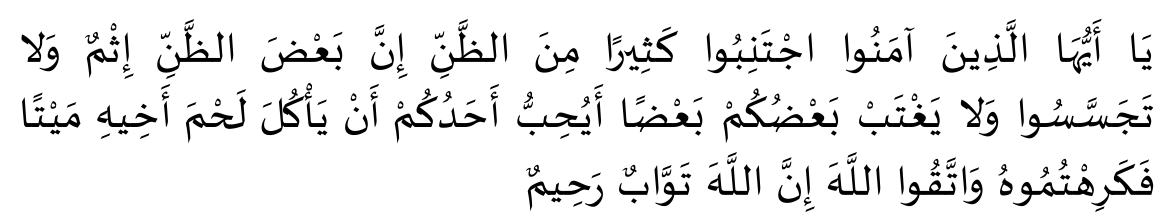

"O you who believe! Avoid many suspicions, indeed some suspicions are sins. And spy not, neither backbite one another. Would one of you like to eat the flesh of his dead brother? You would hate it (so hate backbiting). And fear Allah. Verily, Allah is the One, who accepts repentance, Most Merciful." 
God prohibits human beings from blaspheming one another because they worship the same God. The Qur'an Chapter AlBaqarah (2):139 says:

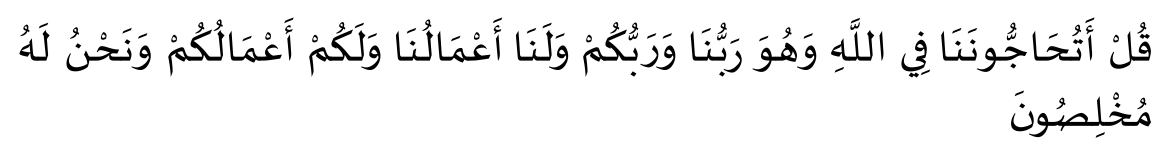

"And say, "Dispute you with us about Allah while He is our Lord and your Lord? And we are to be rewarded for our deeds and you for your deeds. And we are sincere to Him in worship and obedience."

It can be understood that Islam presents several fundamental principles regarding the existence of the other groups or religions. First, either diversity or plurality is taken for granted. ${ }^{17}$ Second, concerning the difference in religion, Muslims have to understand, respect and avoid blasphemy against the others. Third, judging the salvation of beliefs is God's prerogative rights. Fourth, human beings have to respect and help each other because they essentially worship the same God. Several prohibitions of destruction and murder such as in the Qur'an Chapter al-Nisā' (4): 92 and the Qur'an Chapter alMāidah (5): 32 complete those Islamic principles.

The conceptions of Hinduism can be revealed in the Veda and its exegesis such as said in the following verse:

"I unite your thoughts and steps to create peace among you. I guide those who commit wrongdoing to the right path" (Atharva-Veda III. 8.5).

Hinduism explicitly commands humans to create peace and establish friendship not only with the people from the same belief, but also with those who are on "the wrong path". God himself guides those who walk on the wrong path to the right track.

The Atharva-Veda 111. 30.4 obviously commands humans to create peace, "O mankind! Unite and create peace as Gods

${ }^{17}$ Muhhammad 'Imarah explained that plurality is sunatullah (God's decision). Only Allah is the absolute unity. See Muhammad 'Imāra, alTa'addudiyab: al-Ru'yah al-Islamiyah wa al-Tahaddiyah al-Gharbiyah (Mesir: Dār al-Nahḍah, 1997), 4. 
unite. I bestowed the same thing to you. Thereupon, bring about unity among you."

Similarly, the Rig-Veda X.191.2 commands Hindus to build harmony with the others, "O mankind! Live in harmony and peace! Unite and cooperate! Speak in one language and make a decision with one thought. As the people in the past did their obligations, do not be uncertain in doing your obligations." (RigVeda X.191.2)

In humans' interaction, various problems such as disagreement, dispute and conflict arise. If they face them, they have to conduct discussions to reach an agreement. Look at the following verse:

'O mankind! Think together! Discuss together! Unite your heart and thought! I bestowed the same thought and idea for your peace."(Rig-Veda X.191.3). This verse denotes that discussion is suggested as a civilized way of solving problems and building mutual understanding. Similarly, the Rig-Veda X.191.4asserts, "O mankind! Have the same attention! Build mutual understanding among you! Accordingly, you create peace and unity."

Commands to build peace are also presented in Hinduism susatra. I Made Titib states that wishes for the others are often expressed in daily Hindus' mantras such as "Sarva pram hitakharah" (May all creatures prosperous). Correspondingly, Santi Mantra or Subhasita Mantra suggests several mantras such as "Sarvesukbinobhavantu, sarce bantu niramayah, sarvebhadaranipasyantu, ma kasciddubkhabhagbhawet" (May all achieve happiness; May all reach peace; May mutual understanding grows; May all are free from sufferings). Such views basically are based on the Veda, which states, "All creatures are related (vasudhaiva)." These teachings are in accordance with the tradition of menyamabrayathat can be understood as the tradition of treating others as our relatives. ${ }^{18}$

${ }^{18} \mathrm{I}$ Made Titib, "Pandangan Agama dalam Meningkatkan Kualitas Kerukunan Umat Beragama Perspektif Hindu," Harmoni Jurnal Multikultural dan Multireligius, Volume II, Number 5, January-March (2003): 39-54 and I Made Titib, "Dinamika Internal Agama Hindu dan Relevansinya bagi 
From Qur'anic and Vedic verses above as well as Hinduism Susastra, it is obvious that peace building among different religious communities is a fundamental principle in both Hinduism and Islam. A further question is how Hindus and Muslims in Mataram understand their religious teachings? Do they understand those values appropriately?

Most of Hindus and Muslims in Mataram allow others to practice their religions. They consider that it is God who judges the truth. Regarding the religious plurality, Muslims often cite one verse in the Qur'an Chapter al-Kāfirūn (109) verse 6 saying "lakum di nukum waliya-di $n$ " meaning "For you your religion, and for me my religion."19

The head of Karang Tapen kampong said, "In my opinion, it depends on each person's belief. Because I am a Muslim, I believe that Islam is the best religion. If others believe differently, they can do so." In the same vein, Bukhori also stated, "Belief affairs are personal. We cannot compel our belief to the others." Ustadz Kamal from Nyangget proposed a similar view "Differences in beliefs are common. I follow the Qur'anic verse saying lakum di nukum waliya $d i n$. Thus, people can do worship differently as long as they do not disturb one another." 20

Recognition that every person has a freedom to adhere a religion is also prevailing in the Mataram Hindu community. Made, the head of Karang Jasi kampong said, "All people freely adopt one religion and belief. Faith is personal and related to God." The head of Karang Lelede kampong, the former chairman of Mataram Prison, stated similarly, "Belief in religion is a personal affair. When one reaches 17 years old, he or she has to decide on his or her own. Our relationship is like brotherhood. We have the same blood. There is no difference

Hubungan antar Agama-agama di Indonesia," Harmoni Jurnal Multikultural dan Multireligius, Volume II, Number 8, October-December (2003): 39-65.

${ }^{19}$ Interview with TGH. Mukhtar, the chairman of Majelis Ulama Indonesia/MUI (Council of Indonesian Ulama), Kaling Karang Tapen, Amak Syahrun Kaling Nyangget and Ustad Kamal (Nyangget).

${ }^{20}$ Interview with Jumhar, Bukhori, and Kamal on 18, 19 and 22 July 2011. 
between the bloods of amak kangkung (proletariats) and anakagung (aristocrats). Regarding the Hindu caste system, it is merely about job distribution." 21

Religious diversity does not necessarily hamper communities from cooperating with each other. As Oka Netra, a Hindu figure in Cakranegara, said "Belief-related affairs do not prevent people from social interaction. The organization I am leading, Ikatan Pendukung Kemerdekaan Republik Indonesia (Association of Indonesian Republic Independence Supporters), involves people from diverse religions and ethnicities." 22

Correspondingly, a young Hindu figure, I Ketut Nata, the chairman of Kesatuan Hindu Dharma Indonesia/KMHDI (Unity of Indonesian Dharma Hindus) in Mataram, stated, "I have many Muslim relatives. I think that the most important thing is that we do not insult the others' beliefs. Your religion is yours and my religion is mine. In our society, we socialize with humanism."

Recognition and respect for other beliefs or religions do not lead a person to involve in their religious activities. There is limitation for interreligious tolerance. It is restricted to social activities; it does not mean participation in religious rituals of the others. Both Hindus and Muslims agree to build interaction and communication. They freely conduct social transactions. They meet in public spaces such as markets and schools. Relation between Muslim merchants and Hindu traders takes place naturally. Interaction between the Hindus in Saksari as landowners and the Muslims in Nyangget as workers happens naturally for generations. Similarly, village meetings involving people from Karang Tapen, Karang Jasi and Karang Lelede are conducted well. Communication among them runs well. They use Indonesian as the main language and sometimes use Sasak. They understand each other.

${ }^{21}$ Interview with Kaling Karang Lelede on 26 July 2011

22Interview with Oka Netra on 28 August 2011. Oka Netra stated that the Prophet Muhammad inspires peace movement conducted by Hindu figures such as Mahatma Gandi. 


\section{New Bonding: Ethnic and Religious Intermarriage}

In comparison to other factors, marriage is a unique social aspect. Ethnic and religious intermarriage does not necessarily lead to a conflict, but it can contribute to social cohesion. Social cohesion is often built on kinship through marriage. ${ }^{23}$ Thus, marriage is a mean for assimilation. ${ }^{24}$

A couple of intermarriage may find difficulties at the beginning, but eventually all family members accept their marriage. Such marriage contributes to the establishment of strong kinship for subsequent years. Many parents, who opposed intermarriage at first, they eventually accept that fact when their children are persistent to do so.

The Lombok history record shows that intermarriage has existed for a very long time. A widespread ethnic and religious intermarriage was between the Hindu King of Mataram and Dende Aminah or Dende Nawangsasih, a daughter of East Lombok aristocrat. The marriage, which was reportedly conducted because of a divine inspiration suggesting the King to marry a Sasak girl, had enormous political implications at that time. Because the princess got married to the Hindu King while she insisted in her Islam, the Karangasem Kingdom in Mataram applied soft policies to Muslims including the ease of performing pilgrimage for Sasaks. ${ }^{25}$ On the princess' request, a

${ }^{23}$ In sociological studies, religious or ethnic intermarriages are considered the highest construct of social integration. Ethnic marriages, intermarriages, mixed marriages, interracial marriages or trans-national marriages can be used to measure the level of integration and to determine policies in developing social integration. One of studies on intermarriages is Z Qian, \& D. T. Lichter, "Social Boundaries and Marital Assimilation: Interpreting Trends in Racial and Ethnic Intermarriage" American Sociological Review, 72 (2007): 68-94; D. Fong, "Low Rate of German-Turkish Marriages Impedes Integration" Deutsche Welle (2008), http://www.dw-world.de (accessed on 17 March 2011).

${ }^{24}$ Physical assimilation occurs because ethnic or racial intermarriages produce a new group or race. Alo Liliweri, Prasangka dan Konflik, Komunikasi Lintas Budaya Masyarakat Multikultur (Yogyakarta: LKIS, 2009), 138.

25 According to Martin van Bruinessen's record, cited in Fathurrahman Zakaria, at that time Sasak people found difficulties in performing pilgrimage, but because the marriage between the King and Dende Aminah, 
mosque was built in the palace area. This intermarriage also became a good precedence for the future kings to develop harmonious relationship with Sasaks.

Intermarriage is an inevitable social reality. Kinship is built from such marriage. A number of informants told that they had kinship with some Sasak relatives. For example, I Gusti Ngurah Sugatha from Cakranegara, the head of Balinese-Sasak Youths Association, said that he had an extended Muslim family in Central Lombok where his mother came from. Izul Islam, the former mayor deputy of West Lombok, also has a kinship with I Gusti Biarsa, a descendant of the Mataram Hindu King. ${ }^{26}$

Today, several intermarriage couples, whom I met, stated that their difficulties in the first phase of their marriages would diminish when they could convince their families that their couples were the right choices. Eventually, their relationships were normally established. Hatred has been reduced. Each party could receive their children's decisions. When they passed through this phase, kinship has taken place. A new kinship was built when two families from different ethnicities and religions visited one another. They invite each other when a member of a family has a feast and provide assistances reciprocally when they are needed.

That is the case of kinship networks through intermarriage between Hindu-Balinese and Muslim-Sasaks. People's orientation in kinship is maintained through conceptions and beliefs such as the prohibition of breaking relationship.

Kinship networks resulted from intermarriage allow many different parties to restrain conflicts. I discovered a lot of parents' advice to their children to consider their brothers and sisters' feelings. "There is no use of making trouble. In fact, Made (a Hindu name) and Fulan (a Muslim name) are descended from the same ancestors," is a standard advice I heard from the dialogues with many informants. Another suggestion such as "Get along with your friends carefully. Do not quarrel with them. They are our brothers/sisters," is always delivered to

pilgrimage was easier. See Fathurrahman Zakaria, Mozaik Budaya Orang Mataram..., 115.

26Interview with I Gusti Ngurah Sugatha on 16 August 2011. 
young men or women when they socialize with their friends from different religious communities. Families and other social institutions play an important role in the internalization of tolerance value in social interactions.

However, such social integration patterns have always been challenged. Moderate religious views likely accept interethnic and interreligious kinship. Nonetheless, changes may happen when a new pattern of religiosity, which emphasizes religious exclusiveness and fundamentalism, appears. As a result, groups' primordialism enhances.

\section{Semeton Sasak and Batur Bali: Interpersonal Trust Enhancement}

Lombok society has been developing interreligious tolerance as a part of the social integration process. Hindu Balinese's existence in Lombok creates a unique harmonious relationship pattern. Semeton Sasak and Batur Bali are two terms representing people's harmony. Balinese often use semeton Sasak (Sasak brother) to call their Muslim-Sasak neighbors. Correspondingly, Sasaks call their Hindu-Balinese neighbors with batur Bali (Balinese friend). Religious identities such as "Hindu" or "Islam" are rarely or hardly used in addressing someone. The use of ethnic identity address is preferred than that of religious identities.

The terms of Semeton Sasak and Batur Bali seem simple, but they have deep meanings. Semeton Sasak and Batur Bali are more than addressing or calling, but they convey friendship and kinship. The word semeton reflects one's sincere recognition that a person whom he or she calls is a part of himself or herself. Such terms would not be created when religious stigma and stereotypes still existed. There is interpersonal trust between the people using those words.

Interpersonal trust raises people's awareness to develop cooperation and participation in the establishment of wider civic networks. ${ }^{27}$ Trust is a fundamental element in civic networks. As Putnam says, "trust lubricates social life". ${ }^{28}$

${ }^{27}$ Research shows that the level of the Hindus' trust on the Muslims is higher than that of Muslims on Hindus. Unfortunately, that research did not provide convincing evidence about the relation between religious allegiance 
A further question arises, where does trust come from? Does religion contribute to interpersonal trust? According to Putnam, Inglehart ${ }^{29}$ and Saiful Mujani, ${ }^{30}$ interpersonal trust is closely related to the whole heritages of humans' history including economic, politic and religious factors.

Regarding religion, Inglehart recorded that diverse religious traditions create different levels of interpersonal trust. Inglehart's surveys in many countries showed a surprising finding. He pointed out that the level of interpersonal trust in Protestant and Confucian communities is higher than that of Catholic and Muslim communities. He further explained that the low level of interpersonal trust in the Catholic community because of their authoritative and hierarchical religious leadership. The rigid relationship between the Christian central authority and their followers raises low interpersonal trust. ${ }^{31}$

Following Inglehart's logic, it can be assumed that interpersonal trust amidst Hindus is low because of their rigid religious authority and hierarchy. In Hinduism, not all Hindus can apply their religious teaching freely without guidance and direction from their religious leaders. Furthermore, the caste system that divides Hindus into Brahman, Kshatriya, Waisya and Sudra has firmly existed and hence influenced their relationship and interpersonal trust.

Inglehart's international surveys demonstrated that the level of interpersonal trust in countries where Muslims are the majority such as Turk, Bangladesh, Azerbaijan and Nigeria is

and level of trust or trustworthiness. See Olaf Johansson Stenman, Minhaj Mahmud, and Peter Martinsson, "Trust and Religion: Experimental Evidence from Bangladesh,"Keele Economics Research Papers (kerp) 2006/10.

${ }^{28}$ Robert D. Putnam, Making Democracy Work..., 3. See also Francis Fukuyama, Trust: The Social Virtues and the Creation of Prosperity (New York: Simon and Schuster, 1995).

29Ronald Inglehart, "Trust, Well-Being, and Democracy," in Democracy and Trust, ed. Mark E. Warren (Cambridge: Cambridge university Press, 1999), 88.

30Saiful Mujani, Muslim Demokrat: Islam, Budaya Demokrasi, dan Partisipasi Politik di Indonesia Pasca Orde Baru (Jakarta: Gramedia Pustaka Utama, 2007), 121.

${ }^{31}$ Ronald Inglehart, "Trust, Well-Being, and Democracy..., 92-93. 
extremely low. 32 Unfortunately, Inglehart did not explain why this happens.

Saiful Mujani provides a further explanation about the relation between religious traditions and interpersonal trust. Saiful Mujani criticizes Inglehart's finding. Saiful Mujani argues that the relation between religious traditions and interpersonal trust involves many factors. He asserts that the low level of interpersonal trust among Muslims in Indonesia as it was showed in 2001 and 2002 surveys was not only closely related to Islam as a religion, but also to political conditions after the downfall of Suharto when political stability and economy decreased drastically. The low level of people trusts to the government officials, who had bad performances, and corruption in bureaucracy had made people apathetic toward law enforcement officers. All of these led to a lack of interpersonal trust and suspicions. ${ }^{33}$

Relatively unstable state security and economic hardship also have created interpersonal mistrust. Moreover, economic crisis, which has been inflicting Indonesia since the downfall of Suharto, has contributed to the low level of mutual trust in Indonesia. In such hard economic conditions, people became suspicious to the others easily. Furthermore, social conflicts occurred in many places at that time. Thus, it can be concluded that the level of interpersonal trust is not merely caused by religious traditions, but also prevailing economic and political conditions.

The terms of Semeton Sasak and Batur Bali in addressing a person show that religious identities are considered personal and hence needless to express. All people are eligible to live with their religions. I found such awareness from all informants. The use of the terms also implies forgiveness about the painful

32In World V alue Survey by Inglehart, only 20 percent of the respondents trusted the others. It means that less than 2 of 10 people in countries where Muslims are majority trust the others. This is relatively similar to the level of trustworthiness of the others in Indonesia. Surveys in 2001 and 2002 showed that only 1 of 10 Indonesians trusted the others. Mujani, Muslim Demokrat, 125-126.

33SaifulMujani, Muslim Demokrat..., 126. 
history. The Sasak community has forgiven the Balinese colonization. Similarly, existing Hindu-Balinese generation, who have nothing to do with their ancestors' colonization, restrain their emotion from being provoked. This eventually creates harmony in Lombok.

In addition, efforts in building a peaceful relationship between the Hindu-Balinese community and the Muslim-Sasak community can be observed in their theological creativities in accommodating diversities. Theological construction embodies in Hindu rituals as I Made Bambang described as follows:

"When Balinese enter to some most sacred temples such as Lingsar Temple or Narmada Temple, they serve offerings that are prepared in holy manners. We have to do it seriously. If one has a particular intention, he or she usually brings a chicken slaughtered by a Muslim. We also bring the coconut water taken from a mosque. This is because a mosque is a place where religious prayers are regularly conducted." 34

Such theological construction implies religious inclusiveness by recognizing other religions' truth and salvation and reinforces interreligious cooperation. Theological conception in asking a Muslim to slaughter a chicken or in taking a coconut from a mosque signifies religious inclusiveness. This emerges and is reinforced due to the prevailing kinship manifested in the terms of Semeton Sasak and batur Bali.

\section{Conclusion}

Civic ties or social bonding between the Hindu community and the Muslim community in Mataram Lombok Indonesia reinforces social integration due to several factors. First, Islamic and Hinduism theologies promote harmony, tolerance, and mutual respect as well as prohibit blasphemy against other religious beliefs. As has been described previously, both Hindu and Muslim communities in Mataram have relatively inclusive religious views. Religious inclusiveness motivates different religious adherents to allow the others to apply their religions. In addition to inclusive religious attitudes, local wisdom deriving from traditional values contributes to social integration processes.

${ }^{34}$ Interview with I Made Bambang on 18 July 2011. 
Second, new kinship is established through ethnic and religious intermarriage. In this context, intermarriage leads to two processes. In the early phase of intermarriage, it may trigger tensions and conflicts between bride and groom's families. Nonetheless, when such critical phase is overcome, intermarriage creates new kinship that unites an extended family of different ethnicities and religions.

Third, reinforcement of interpersonal trust is a core of the establishment of peaceful relations between Muslims and Hindus. Interpersonal trust persuades the Sasak community to respect and accept the Balinese and vice versa. It manifests in the use of terms of Semeton Sasak (Sasak brother) and Batur Bali (Balinese friend) in addressing each other. Although the terms are relatively simple, they imply acceptance, respect, and recognition that all people have equal opportunities to live and grow together in Lombok Island. Wa al-Lāh a làm bi al-sawāb.

\section{References}

'Imārah, Muhammad. al-Ta'addudiyah: al-Ru'yah al-Islämiyah wa alTahaddiyah al-Garbiyah. Mesir: Dār al-Nahdah, 1997.

El Fadl, Khaled Abou. The Place of Tolerance in Islam. Boston: Beacon Press, 2002.

El Fadl, Khaled Abou. Speaking in God's Name: Islamic Law, Authority and Women. Oxford: One World Publication, 2001. al-Asfahanī, al-Ḥusayn bin Muhammad al-Rāgib. Mu'jam alMufradat li al-Alfāą al-Qur'ān. Beirut: Dār al-Kutub al'Ilmiyyah, 1997.

al-Qurtubī, 'Abd Allāh bin Muḥammad bin Ạ̣mad al-Anṣari. Al-jāmi' li Aḅkām al-Qứàn. Egypt: Dār al-Kutub alMișriyyah, n.d.

Fong, D. "Low Rate of German-Turkish Marriages Impedes Integration." Deutsche Welle (2008), http://www.dw-world.de (accessed on 17 March 2011).

Harnish, David. "New Lines, Shifting Identities: Interpreting Change at the Lingsar Festival in Lombok, Indonesia.," Ethnomusicology, Vol. 49, No. 1 (Winter, 2005): 1-24 
http://www.jstor.org/stable/20174351. (Accessed on 12 February 2015).

Inglehart, Ronald. "Trust, Well-Being, and Democracy." In

Mark E. Warren, Democracy and Trust, edited by Mark E.

Warren. Cambridge: Cambridge University Press, 1999.

Liliweri, Alo. Prasangka dan Konflik, Komunikasi Lintas Budaya Masyarakat Multikultur. Yogyakarta: LKIS, 2009.

Mujani, Saiful. Muslim Demokrat: Islam, Budaya Demokrasi, dan

Partisipasi Politik di Indonesia Pasca Orde Baru. Jakarta:

Gramedia Pustaka Utama, 2007.

Peters, Karin. Living Together in Multi-Ethnic Neighborhoods: The Meaning of Public Spaces for Issues of Social Integration.

Wageningen: Wageningen Academic Publisher, 2011.

Pigeaud, Th.G. Literature of Java. Vol I. Synopsis of Javanese Literature 900-1900 AD. The Hague: Martinus Nijhoff, 1967.

Poerbatjaraka, P. Voorhoeve, and C. Hooykaas. Indonesische Handschriften. Bandung: A.C. Nix\&Co, 1950.

Fukuyama, Francis. Fukuyama, Trust: The Social Virtues and the Creation of Prosperity. New York: Simon and Schuster, 1995.

Qian, Z, and D. T. Lichter. "Social Boundaries and Marital Assimilation: Interpreting Trends in Racial and Ethnic Intermarriage." American Sociological Review, 72 (2007): 68-94.

Ross, Marc Howard. Cultural Contestation in Ethnic Conflict. New York: Cambridge University Press, 2007.

Stenman, Olaf Johansson, Minhaj Mahmud, and Peter

Martinsson. "Trust and Religion: Experimental Evidence from Bangladesh."Keele Economics Research Papers (kerp) 2006/10.

Tim Penyusun Parisada Hindhu Dharma. Upadesa tentang Adjaran-adjaran Agama Hindu. Jakarta: Penerbit Sub Projek Bimbingan Penyuluhan dan Dakwah Direktorat Jendral Bimas Hindu dan Budha Depag RI, 1970.

Tinggen, I Nengah. Pedoman Perubahan Ejaan Bahasa Bali dengan Huruf Latin dan Huruf Bali. Singaraja: UD. Rikha, 1993.

Titib, I Made. "Dinamika Internal Agama Hindu dan Relevansinya bagi Hubungan antar Agama-agama di Indonesia." Harmoni Jurnal Multikultural dan Multireligius, Volume II, Number 8, October-December (2003): 39-65. 
Titib, I Made. "Pandangan Agama dalam Meningkatkan Kualitas Kerukunan Umat Beragama Perspektif Hindu." Harmoni Jurnal Multikultural dan Multireligius, Volume II, Number 5, January-March (2003): 39-54.

Williams, Rhys H. "The Language of God in the City of Man: Religious Discourse and Public Politics in America." In Corwin Smidt, ed., Religion as Social Capital: Producing The Common Good edited by Corwin Smidt, 171-190. Waco, Texas: Baylor University Press, 2003.

Zakaria, Fathurrahman. Mozaik Budaya Orang Mataram. Mataram: Yayasan Sumurmas Al-Hamidy, 1998. 